\title{
RELEVANSI NILAI RITUAL TOLAK BALA LANTING BAMBAN PADA PENCEGAHAN DAMPAK PANDEMI COVID-19
}

\author{
Kunti Ayu Vedanti \\ IAHN Tampung Penyang Palangka Raya \\ kuntiayuvedanti@gmail.com
}

\begin{abstract}
Riwayat Jurnal
Artikel diterima:

Artikel direvisi:

Artikel disetujui:

Kata Kunci:

Ritual Tolak Bala

Hindu Kaharingan

COVID-19

Keyword:

Ritual Tolak Bala

Hindu Kaharingan

COVID-19

\section{Abstrak}

WHO mendeklarasikan COVID-19 sebagai pandemi global dan berdampak bagi masyarakat dunia. Dampak yang ditimbulkan dirasa kompleks, membutuhkan kepedulian dan peran serta semua lapisan masyarakat, tidak terkecuali umat Hindu untuk pencegahan hingga penanganannya. Menggunakan metode desktiptif kualitatif, meneliti Ritual Tolak Bala Lanting Bamban sehingga menghasilkan relevansi nilai terhadap pencegahan dampak pandemi COVID-19, yaitu; 1) nilai pengorbanan tulus ikhlas yang dapat diimplementasikan dengan sikap peduli kepada sesama manusia dan lingkungan sekitar, untuk mencegah dampak ekonomi pandemi COVID-19 dan 2) nilai hakikat kehidupan yang didasari filsafat agama Hindu, dapat meningkatkan kesadaran spiritual dan ketenangan untuk mencegah dampak psikologis pandemi COVID-19.

\section{Abstract}

WHO declares COVID-19 as global endemic disease and impact to people around the world. It is causes complexity impact on human being and needs people awareness to take in hand it together, as well as Hindu religion society. Based on it phenomenon, this research is using descriptive qualitative method, to find the relevance value of The Ritual Tolak Bala Lanting Bamban to prevent the impact of COVID-19 endemic, that is; 1) the honest sacrifice value as a relevant value to build the action of social care on society, to prevent the economic impact of COVID-19 endemic and 2) the value of reality of life based on Hinduism philosophy to build spiritual awareness and help calmness mind to prevent the psychological impact of
\end{abstract}


COVID-19 endemic.

\section{Pendahuluan}

Pemberitaan mengenai COVID-19 menjadi headline di seluruh dunia, dikenal sebagai virus yang menginfeksi jutaan manusia dan mengakibatkan ribuan korban jiwa. COVID-19 atau novel coronavirus 2019 pertama kali ditemukan di Provinsi Hubei, Republik Rakyat Cina (RRC), kemudian menyebar dengan cepat hingga pada tanggal 30 Januari 2020 WHO menetapkan virus tersebut sebagai pandemi global (Velavan\& Meyer, 2020:278) Penyebaran tersebut dikarenakan interaksi hingga migrasi orang dari wilayah Republik Rakyat Cina. Setidaknya hingga artikel ini ditulis, secara global sebanyak 2.319.006 jiwa terinfeksi dan 157.970 jiwa meninggal dunia (data tertanggal 21 April 2020 dari laman https://covid19.go.id.) Hal tersebut menurut World Health Organization (WHO) dikarenakan karakteristik COVID-19 yang mudah bertransmisi dari satu orang ke orang lainnya, bahkan pada kasus orang terinfeksi yang tidak bergejala. WHO juga telah menetapkan COVID-19 sebagai darurat global dan seluruh dunia diharapkan waspada untuk menghadapinya (Sohrabi et al., 2020:71-72)

Lebih lanjut pada artikel Journal of Risk and Financial Managemen yang menganalisa pandemi COVID-19 yang terjadi di Republik Rakyat Cina, ditemukan berbagai dampak pandemi ini terhadap kehidupan masyarakat, diantaranya dampak resiko terhadap kestabilan dan pertumbuhan ekonomi suatu wilayah atau negara, dampak resiko terhadap korban jiwa apabila tidak memadainya fasilitas dan SDM tenaga medis dalam penanganan pasien, hingga berdampak pada pendidikan dan pemerintahan diakibatkan pembatasan sosial. (Wang et al., 2020:36) Beragam dampak yang dikemukakan pada artikel ilmiah Journal of Risk and Financial Managemen tersebut dirasa merupakan dampak global di wilayah yang terinfeksi pandemi COVID-19. Sejalan dengan itu, mengutip CNN Indonesia, berita daring tanggal 06 April 2020, Menteri Keuangan RI menganalisa bahwa dampak COVID-19 bagi Indonesia akan lebih kompleks dibandingkan krisis yang terjadi pada tahun 1997-1988 dan 2008-2009. Wabah ini tidak hanya berdampak pada nyawa tapi juga bagi perekonomian

Dampak dan resiko yang diakibatkan pandemi COVID-19 diketahui tidak hanya tentang kehidupan sosial, ekonomi, dan beragam permasalahan fisik. Namun juga memberi dampak psikologis bagi individu. Dampak pandemi ini terhadap psikologis seseorang dapat dikarenakan kehilangan sumber penghasilan, ketakutan akan pandemi, kepanikan hingga 
depresi. Setidaknya beberapa negara telah menyadari dampak psikologis yang mengikuti pandemi COVID-19 tersebut, sebagaimana antisipasi yang dilakukan negara Republik Rakyat Cina, Australia dan Singapura dengan menerapkan Telemental Health Sevice, yaitu metode pelayanan kesehatan dan terapi kesehatan mental menggunakan media komunikasi dan internet yang memungkinkan setiap orang dapat memanajemen kondisinya dan menemukan solusi untuk mengurangi kecemasan. Metode ini dianggap tepat sasaran dan mampu membantu pemerintah untuk meminimalisir dampak psikologis dari pandemi COVID-19. (Zhou et al., 2020:377-379)

Merujuk pada perkembangan pandemi COVID-19 di dunia dan dampak yang mengikutinya, dibutuhkan peran serta dan kecakapan masyarakat dalam tindakan pencegahan hingga penanganan COVID-19 di Indonesia. Pada tindakan pencegahan, masyarakat dapat berperan aktif dengan menerapkan pola hidup sehat, peduli terhadap kebersihan, disiplin melaksanakan pembatasan sosial, dan meningkatkan keimanan kepada Tuhan Yang Maha Esa. Sedangkan pada tahap penanganan, dibutuhkan pengetahuan yang memadai dari masyarakat tentang prosedur penanganan COVID-19. Hal tersebut selalu ditekankan oleh Presiden Jokowi dalam setiap pidatonya pada masa Pandemi COVID-19 di Indonesia. Sejalan dengan anjuran tersebut, umat Hindu memiliki kewajiban yang sama untuk turut serta mensukseskan tujuan bersama agar terhindar dari pandemi COVID-19 dan dampaknya.

Upaya yang dapat dilakukan umat Hindu adalah menginternalisasikan ajaran keagamaan Hindu yang dapat mendukung pencegahan dampak pandemi ini. Salah satunya adalah dengan menemukan relevansi nilai Ritual Tolak Bala Lanting Bamban umat Hindu Kaharingan di Kelurahan Tangkiling Kota Palangka Raya pada pencegahan dampak pandemi COVID-19. Ritual Tolak Bala umunya dikenal sebagai ritual yang dilaksanakan untuk menolak malapetaka, marabahaya dan kemalangan. I Gde Wayan Soken Bandana, dalam bukunya Ritual Tolak Bala Masyarakat Bali menyajikan ragam Ritual Tolak Bala yang dilaksanakan umat Hindu di Bali (Bandana, 2009:2-4). Namun, pada penelitian ini memiliki perbedaan dengan Ritual Tolak Bala yang dilakukan oleh masyarakat Hindu Kaharingan di Kota Palangka Raya, Kalimantan Tengah, serta belum mengkaji secara mendalam mengenai relevansi nilai terhadap pencegahan dampak Pandemi COVID-19. Sehingga, penelitian tentang Relevansi Nilai Ritual Tolak Bala Lanting Bamban pada Pencegahan Dampak Pandemi COVID-19 merupakan sebuah penelitian yang dibutuhkan untuk memberi 
pemahaman pada masyarakat tentang nilai yang terkandung dalam sebuah ritual, khususnya pada masa Pandemi COVID-19, yang kemudian mampu memberikan sumbangsih terhadap peningkatan kualitas kehidupan masyarakat.

\section{Metode Penelitian}

Penelitian ini menggunakan metode penelitian kualitatif yang menghasilkan data deskritif berupa kata-kata tertulis atau lisan dari orang-orang atau perilaku yang diamati di lapangan (Moleong, 2018:5-6). Peneliti melakukan penelitian dengan observasi partisipatif, yaitu berpartisipasi dan mengamati objek penelitian secara natural di lapangan. Teknik penelitian demikian relevan dengan objek yang diteliti, diharapkan mampu menghasilkan data yang diperlukan (Ghoni \& Almanshur, 2012:73-81). Data yang digunakan adalah dokumentasi foto dan wawancara yang difokuskan pada rohaniwan, tokoh agama dan beberapa umat Hindu yang turut serta dalam Ritual Tolak Bala Lanting Bamban di Kelurahan Tangkiling, Kota Palangka Raya. Menggunakan teori religi Durkheim, yang menyatakan bahwa ritual ada di dalam wilayah sakral, yaitu wilayah supranatural, sesuatu yang superior, berkuasa, tak tersentuh dan selalu dihormati dalam kehidupan masyarakat (Pals, 2011:145) untuk mengkaji secara mendalam tentang Ritual Tolak Bala Lanting Bamban. Selanjutnya, terhadap relevansi nilai ritual tersebut pada pencegahan dampak Pandemi COVID-19, dilakukan analisis lebih lanjut mengklasifikasikan nilai-nilai yang relevan dan dapat diimplementasikan pada masyarakat Hindu.

\section{Pembahasan}

Merupakan salah satu agama besar di dunia, Agama Hindu memiliki kekayaan upacara keagamaan yang tersebar di berbagai belahan dunia.Kekayaan upacara keagamaan tersebut dilandasi universalitas filsafat yang terepresentasi sesuai dengan tradisi setempat. Realita demikian dikarenakan Hindu adalah ajaran dharma yaitu kebenaran sejati yang merupakan inti kehidupan semesta (Pandit, 2003:374-382). Dikenal dengan keunikannya, agama Kaharingan yang berintegrasi dengan agama Hindu pada tahun 1980 (Schiller, 1996:413) memiliki beragam ritual, salah satunya Ritual Tolak Bala Lanting Bamban yang menurut Pinandita Disel Inga, dilaksanakan pada rangkaian Hari Raya Nyepi di Kelurahan Tangkiling, Kota Palangka Raya (Wawancara, 23 Maret 2020)

Hari Raya Nyepi menandai tahun baru pada kalender Tahun Saka, dimaknai sebagai awal menjalani tahun yang baru dengan harapan peningkatan kualitas pribadi terutama pada 
kehidupan spiritual sebagai dasar menjalani keseharian (Wiana, 2009:32) Lebih lanjut, Budi Purnomo menjelaskan bahwa konsep utama pelaksanaan Hari Raya Nyepi adalah Catur Bratha Penyepian yang merefleksikan harapan umat Hindu untuk dapat meningkatkan kualitas diri dengan lima aturan, yaitu; Amati Geni (tidak menyalakan api), Amati Karya (tidak melakukan pekerjaan), Amati Lelungan (tidak bepergian), dan Amati Lelanguan (tidak bersenang-senang). Selain Catur Bratha Penyepian, Hari Raya Nyepi umumnya memiliki rangkaian pelaksanaan. Rangkaian pelaksanaan dimulai dengan persiapan, pembersihan hingga puncak Perayaan Nyepi. Pada umat Hindu di Kelurahan Tangkiling, Pecaruan dilaksanakan dengan Ritual Lanting Bamban yang dilangsungkan pada satu hari sebelum puncak perayaan Nyepi (wawancara, 23 Maret 2020).

\section{Prosesi Ritual Tolak Bala Lanting Bamban Umat Hindu di Kelurahan Tangkiling Kota Palangka Raya}

Ritual Tolak Bala pada umat Hindu dipahami sebagai ritual untuk menangkal kesialan, malapetaka dan marabahaya dalam kehidupan (Bandana, 2009:2). Secara umum, Ritual Tolak Bala Lanting Bamban memiliki kemiripan fungsi dengan Ritual Tolak Bala yang dilakukan masyarakat Bali, yaitu bertujuan untuk mendoakan dan memohon keselamatan.

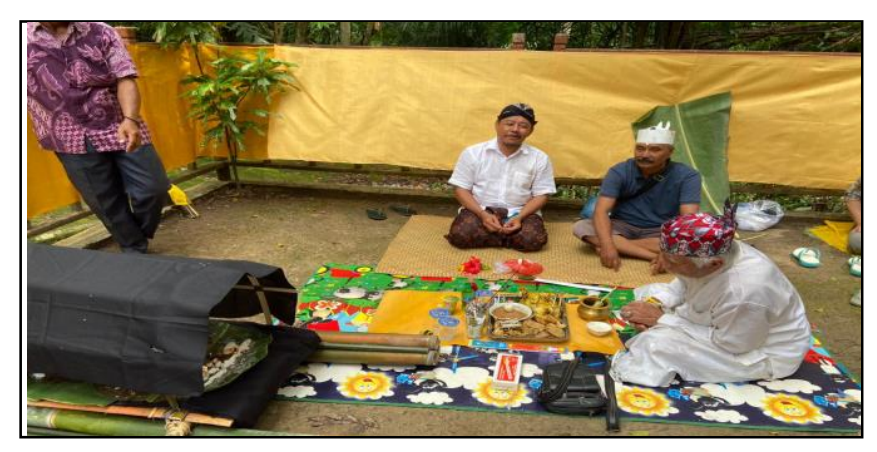

Gambar 5. Pelaksanaan Ritual Tolak Bala Lanting Bamban

Pelaksanaan Ritual Tolak Bala Lanting Bamban dilaksanakan secara bersama-sama oleh umat Hindu Kaharingan di Kelurahan Tangkiling, Kota Palangka Raya dengan menggunakan media berupa Lanting Bamban atau rakit bambu kecil yang diisi dengan sesajen dan sarana tolak bala. Ritual Tolak Bala Lanting Bamban dipimpin oleh rohaniawan dengan melantunkan mantra-mantra. Lebih lanjut dijelaskan Pinandita Disel Inga, memiliki prosesi sebagai berikut:

\section{Proses persiapan sesaji dan upakara (sarana ritual)}


Persiapan sesaji atau upakara dilaksanakan oleh rohaniawan dengan menggunakan pedoman yang sesuai dengan aturan turun temurun umat Hindu Kaharingan. Sesaji atau upakara yang digunakan pada Ritual Tolak Bala Lanting Bamban yang utama adalah sebagai berikut:

1. Patung Sadiri, yaitu patung berbentuk manusia laki-laki dan perempuan atau disesuaikan dengan tujuan tolak bala yang terbuat dari tepung beras. Patung Sadiri ini kemudian diberi alas daun pisang.

2. Rangkan panginan simpan, yaitu sesaji berupa makanan sesuai dengan ketentuan, diantaranya adalah katupat, telur, kue cucur, lamang/ketan, dan dilengkapi dengan air minum berupa baram dan air putih.

3. Sipa ruku, yaitu sirih pinang (panginangan) dan rokok tembakau yang juga disiapkan untuk kelengkapan sarana.

4. Dupa atau parapen.

5. Behas Tambak, yaitu beras yang ditempatkan di sebuah mangkuk dilengkapi dengan giling pinang rukun tarahan serta behas hambaruan.

6. Behas Hambaruan, yaitu beras yang dipilih sebanyak tujuh butir dan dibungkus dengan kain putih.

7. Lanting Bamban, yaitu sebuah rakit terbuat dari bambu berukuran kecil yang beratapkan kain hitam dan dilengkapi bendera kuning kecil di sisinya, berfungsi untuk menempatkan sesaji yang akan dihanyutkan di sungai.

8. Behas tawur, adalah beras yang dicampur dengan minyak kelapa, kunyit, emas dan perak tabur sebagai sarana menyampaikan doa-doa.

9. Sarana Mamapas, yang terdiri dari daun kangkawang papas, sawang gagar, sawang belum, dan kayu palis yang diikat dan dijadikan satu untuk melaksanakan pembersihan diri dengan menggunakan media danum nyanyah (air cucian beras dan kerak nasi).

10. Lilin atau lampu sumbu untuk diletakkan di dalam Lanting Bamban.

\section{Proses Pelaksanaan Ritual Tolak Bala Lanting Bamban}

Tahapan lanjutan menurut Pinandita Disel Inga, setelah sarana dan sesaji disiapkan adalah melaksanakan prosesi Ritual Tolak Bala Lanting Bamban, yaitu: 
1. Menempatkan potongan kuku tangan dan kaki, potongan rambut, kain pakaian, dan air kunyahan sirih pinang di Patung Sadiri. Adapun prosesi ini adalah simbol Patung Sadiri sebagai pengganti diri yang akan menggantikan untuk menerima kesialan dan wabah penyakit.

2. Rohaniawan manawur atau melantunkan doa-doa, dengan tujuan memohon kepada RanyingHatalla Langit, Tuhan Yang Maha Esa melalui manifestasi sucinya, Sahur Parapah dan Sangiang untuk menyertai ritual suci yang dilakukan agar diberikan keselamatan.

3. Mamapas atau membersihkan diri yang dilakukan rohaniawan bertujuan untuk membersihkan marabahaya, kesialan dan penyakit yang melekat pada diri.

4. Memasukkan Patung Sadiri, sesaji, behas tambak dan lilin ke dalam Lanting Bamban.

5. Menghanyutkan Lanting Bamban di sungai dengan tujuan membuang kesialan dan penyakit yang ada di diri manusia agar dapat memulai kehidupan dengan harapan baru.

6. Mambuwur behas hambaruan atau menerima berkat RanyingHatalla Langit melalui behas hambaruan yang diletakkan di behas tambak (Wawancara, 24 Maret 2020).

\section{Relevansi Nilai Ritual Tolak Bala Lanting Bambanpada Pencegahan Dampak PandemiCOVID-19}

Kompleksitas dampak dari pandemiCOVID-19 terhadap kehidupan masyarakat merupakan tantangan bangsa tanpa terkecuali umat beragama. Anjuran pemerintah untuk peduli kebersihan, melakukan physical distancing, social distancing, menjaga kesehatan serta meningkatkan keimanan kepada Tuhan Yang Maha Esa diharapkan mampu menjadi amunisi memerangi pandemi ini. Sependapat dengan pemerintah, Ritual Tolak Bala Lanting Bamban memiliki relevansi terhadap penanganan dampak pandemiCOVID-19, yaitu:

\section{Relevansi Nilai Pengorbanan Tulus Ikhlas (Yajna) Terhadap Peningkatan Solidaritas Sosial pada Pencegahan Dampak Ekonomi pada Pandemi COVID-19}

Pelaksanaan Ritual Tolak Bala Lantinng Bamban didasari keyakinan umat Hindu Kaharingan bahwa Ranying Hatalla Langit beserta manifestasinya akan menolong umat manusia dalam menjalani kehidupannya. Pada Pasal 29 dalam Kitab Suci Panaturan, Ranying Hatalla Langit bersabda bahwa Raja Bunu dan keturunannya sebagai umat manusia dapat memohon pertolongan dalam menjalani kehidupannya dari Raja Sangiang dan Raja Sangen sebagai manifestasi kemahakuasaan Tuhan (MBA-HK, 2009:107-109). Kemudian dengan 
keyakinan tersebut, dikenal berbagai ritual keagamaan Hindu untuk memohon kebahagiaan dan kemudahan dalam kehidupan.

Ritual adalah yajna, yang berarti memuja, mempersembahkan atau memberi pengorbanan dan merupakan wujud dari keimanan terhadap Tuhan (Suarjaya,dkk, 2008:2-6). Filsafat pelaksanaanya, tertulis dalam Kitab Suci Bhagawad Gita, bahwa Yajna adalah sebab keberadaan alam semesta, karena alam semesta beserta isinya ini merupakan bentuk dari Yajna Tuhan. Yajna pula merupakan upaya yang dapat dilakukan manusia guna mendapatkan kebahagiaan dan kebajikan dalam kehidupannya (Bhagawad Gita III.10-11). Yajna dinyatakan sebagai sumber kebahagiaan dan kebajikan bagi kehidupan manusia terkait dengan hakikat yajna yang adalah pengorbanan tulus ikhlas dan persembahan. Melalui pengetahuan tentang nilai yajna dalam ritual keagamaan Hindu tersebut, manusia dapat memahami bahwa keikhlasan dalam memberikan persembahan adalah salah satu wujud bhakti kepada Tuhan atau Ranying Hatalla Langit. Demikian halnya Ritual Tolak Bala Lanting Bamban, merupakan salah satu Yajna yang ditujukan kepada para Bhuta atau penguasa alam bawah untuk menjaga keharmonisan dalam kehidupan bersama di alam ini.

Selain itu, objek yadnya atau pengorbanan tulus ikhlas tersebut hendaknya dipahami secara luas. Yajna yang secara umum diklasifikasikan menjadi lima jenis, atau dikenal dengan Panca Yajna, terdiri dari Dewa Yajna, Rsi Yajna, Pitra Yajna, Manusa Yajna, dan Bhuta Yajna (Suarjaya,dkk, 2008:4-10). Kelima Yajna tersebut dilandasi dengan keyakinan/sraddha terhadap Tuhan/Ida Sang Hyang Widhi Wasa/Ranying Hatalla Langit. Kemudian, dibutuhkan pemahaman tentang Tuhan yang holistik, dalam Brhadaranyaka Upanisad, dinyatakan bahwa "Aku adalah Brahman (atman atau jiva)", kemudian pada Bhagawad Gita, disebutkan "Om Tat Sat, Om! Aku adalah mahluk hidup”, selanjutnya pada Chandogya Upanisad disebutkan bahwa "Aku adalah kamu (Tat Tvam Asi)". Sehingga disimpulkan bahwa Tuhan dalam agama Hindu ada dimana-mana, sebagai inti kehidupan semua mahluk bahkan merupakan sumber kehidupan yang bersemayam dalam diri manusia/Atman (Pandit,2003:320-322).

Berdasarkan konsep ketuhanan tersebut, Tuhan diinterpretasikan berada dimana-mana dan berada dalam semua mahluk. Tujuan dari Yajna yang merupakan pengorbanan suci tulus ikhlas kepada Tuhan berarti pula wujud Tuhan dalam setiap mahluk hidup, termasuk sesama manusia. Interpretasi tersebut menjadi relevan diimplementasikan dalam kehidupan umat Hindu sehari-hari. Kesadaran untuk mencegah penyebaran COVID-19 dapat dilandasi dengan 
keimanan bahwa Tuhan hidup dalam setiap mahluk dan manusia berkewajiban untuk saling menjaga, mengasihi, memerdulikan kehidupan mahluk lainnya dan sesama manusia.

Nilai yajna sebagai pengorbanan suci yang tulus ikhlas dapat pula diimplementasikan pada tindakan saling membantu sesama yang mengalami kesulitan di masa pandemi ini. Sehingga, nilai Ritual Tolak Bala Lanting Bamban umat Hindu dapat meningkatkan semangat umat Hindu dari berbagai profesi untuk ber-yajna sesuai kemampuannya dan melakukan pengorbanan suci agar pandemi ini dapat dilawan bersama-sama.

\section{Relevansi Nilai Hakikat Kehidupan dan Sraddha pada Pencegahan Dampak Psikologis Pandemi COVID-19}

Pelaksanaan Ritual Tolak Bala Lanting Bamban didasari keimanan kepada Tuhan Yang Maha Esa/RanyingHatalla Langit beserta manifestasinya. Filsafat ritual ini adalah pembersihan diri dari segala malapetaka, penyakit, kesialan dan marabahaya, dipahami dari kutipan mantra Ritual Tolak Bala Lanting Bamban, “...manulak sial kawe peres badi calaka bahaya..." yang diterjemahkan “...menolak kesialan, penyakit dan marabahaya...” Umat Hindu Kaharingan meyakini bahwa ritual ini bertujuan untuk membantu kehidupan manusia menjadi lebih baik (Pindandita Disel Inga, Wawancara, 24 Maret 2020).

Pada pelaksanaannya, ritual ini memberi efek psikologis berupa ketenangan dan pengurangan kecemasan. Bapak Ramadi, salah satu umat Hindu di Kecamatan Bukit Batu yang juga mengikuti ritual ini menyampaikan bahwa dirinya dan keluarganya menjadi lebih tenang dan percaya bahwa Ranying Hatalla Langit akan melindungi keluarganya dalam masa pandemi ini. Meskipun, setiap orang tetap harus waspada, menjaga kebersihan dan mengikuti anjuran pemerintah (wawancara, 24 Maret 2020). Efek psikologis demikian merupakan hal positif yang dibutuhkan setiap orang dalam menghadapi pandemi, sehingga kesehatan tubuh dapat lebih terjaga dan tentunya lebih mampu tetap tenang dan waspada dalam menjalani kehidupan kesehariannya.

Dampak yang dirasakan umat Hindu diakibatkan pelaksanaan Ritual Tolak Bala Lanting Bamban tersebut relevan, karena kehidupan beragama memberikan pengaruh terhadap psikologi seseorang ataupun komunitas. Kehidupan beragama memberi pengalaman beragama, hingga memberi pengaruh terhadap perilaku seseorang dalam kesehariannya. Pada tahapan lebih lanjut, pencapaian spiritual memberikan kekhasan perilaku pada sebagian orang (Suasthi \& Suastawa, 2008:1-8). Terkait dengan ritual ini, pengaruh psikologis pada penganut 
agama Hindu Kaharingan, merupakan pengaruh positif yang mampu meningkatkan ketenangan dari doa-doa dan tujuan pelaksanaan ritual yaitu untuk keselamatan dan kebahagiaan.

Ketenangan dan kedamaian yang didapatkan dari aktivitas beragama bersumber dari keyakinan/sraddha umat Hindu Kaharingan kepada Ranying Hatalla Langit, yang merupakan bagian pertama dari Lime Sarahan atau lima keyakinan, yaitu "Ranying Hatalla katamparan”, bahwa Ranying Hatalla/Tuhan Yang Maha Esa adalah awal dari segala yang ada di alam semesta ini (Etika, 2017:99-102). Pada Kitab Suci Panaturan Pasal 1 dinyatakan bahwa Ranying Hatalla Langit adalah awal dari segalanya, yang menciptakan semesta beserta kehidupan di dalamnya (MBA-HK, 2009:1-3). Pasal 21-22 tertulis tentang kodrat manusia sebagai mahluk yang memiliki keterbatasan, dapat menua dan mengalami kematian. Kodrat tersebut diceritakan melalui sosok Raja Bunu sebagai manusia pertama yang ada di dunia. Raja Bunu memiliki keterikatan dengan kehidupan duniawi, disimbolkan dengan kebutuhannya akan makanan dan keadaannya serta anak keturunannya yang mengalami kematian (MBA-HK, 2009:65-71). Kendati demikian, pada pada Pasal 29 Kitab Suci Panaturan, Ranying Hatalla Langit beserta manifestasinya akan senantiasa membantu Raja Bunu menjalani kehidupannya sebagai manusia yang memiliki keterbatasan (MBA-HK, 2009:107-109). Pada pasal 29 tersebut, Ranying Hatalla Langit memberikan motivasi bahwa manusia tidak dibenarkan berpangku tangan menghadapi keadaan, karena Tuhan Yang Maha Esa/Ranying Hatalla Langit dapat menganugrahi kebahagiaan dan solusi dari permasalahan dengan usaha dari manusia atau umatnya. Sehingga pada masa pandemi COVID-19 ini, umat Hindu mampu meningkatkan optimisme dengan keyakinan kepada Ranying Hatalla Langit dalam menjalankan upayanya. Sehingga, manusia dapat selalu melaksanakan kehidupan dan kewajibannya dengan penuh kesadaran, ikhlas, penuh keredahan hati dan bertanggung jawab. Dapat diterapkan dengan berusaha menenangkan diri dengan kesadaran spiritual, selalu bekerja sama dalam upaya menangani COVID-19 dan berdoa kepada Tuhan Yang Maha Esa.

\section{Simpulan}

Pandemi COVID-19 telah merenggut ribuan korban jiwa di dunia. Merupakan pandemi global, COVID-19 menyebar di berbagai wilayah Indonesia dan menjadi tanggung jawab semua lapisan masyarakat, dari berbagai suku, ras, agama dan profesi untuk bekerja sama menanggulanginya. Umat Hindu memiliki tanggung jawab yang sama, salah satunya dengan mengimplementasikan ajaran keagamaan dan ritual yang relevan pada masa kini. Salah satunya adalah Nilai pada Ritual Tolak Bala Lanting Bamban yang dilaksanakan pada 
rangkaian Hari Raya Nyepi setiap tahunnya. Terdapat dua nilai yang relevan dengan upaya penanganan PandemiCOVID-19, yaitu; 1) relevansi nilai pengorbanan tulus ikhlas yang dapat diinterpretasikan berupa kemampuan umat Hindu untuk menyadari hakikat bahwa Tuhan ada di dalam setiap mahluk, sehingga merupakan kewajiban untuk saling membantu dimasapandemi ini dengan sesama yang bertujuan untuk memperoleh kebahagiaan dan kebajikan, sehingga mampu menjadi solusi pencegahan dampak ekonomi dari Pandemi COVID-19, 2) relevansi nilai hakikat kehidupan, yaitu pelaksanaan ritual tersebut didasari keimanan kepada Ranying Hatalla dan manifestasinya, dimaknai sebagai wujud introspeksi diri atas kodrat kehidupannya di dunia sebagai mahluk yang memiliki keterbatasan dan mengalami kematian, sehingga manusia senantiasa berupaya dan berdoa untuk kebahagiaan kehidupannya serta senantiasa tenang menghadapi beragam kesulitan dalam kehidupannya agar terhindar dari dampak psikologis pada masa Pandemi COVID-19. Dengan implementasi nilai Ritual Tolak Bala Lanting Bamban yang relevan pada penanganan dampak pandemi COVID-19 tersebut, umat Hindu dapat berperan aktif, bergotong-royong, meningkatkan keperdulian dan melaksanakan kewajibannya sesuai dengan profesinya secara bertanggungjawab.

\section{Daftar Pustaka}

Bandana, I Gde Wayan Soken. (2009). Ritual Tolak Bala Masyarakat Bali. Denpasar: Pustaka Larasan.

Darmayasa. (2013). Bhagawad Gita (Nyanyian Tuhan). Denpasar: Yayasan Dharma Sthapanam.

Etika Ph.D., Tiwi. (2017). Penuturan Simbolik Konsep Panca Sraddha dalam Kitab Suci Panaturan. Tangerang: AN1MAGE.

Ghony, M. Djunaidi \& Almanshur, Fauzan. (2012). Metodologi Penelitian Kualitatif. Jogjakarta: AR-Ruzz Media.

MB-AHK. (2009). Panaturan. Denpasar: Widya Dharma.

Moleong, Lexy J. (2018). Metodologi Penelitian Kualitatif. Bandung: Remaja Rosdakarya. Pals, Daniel L. (2011).Seven Theories of Religion. Yogyakarya: IRCiSoD.

Pandit, Bansi.(2003). Pemikiran Hindu, Pokok-Pokok Pikiran Agama Hindu dan Filsafat. Surabaya: Paramita.

Sohrabi, et al. (2020). World Health Organization Declares Global Emergency: A Review of The 2019 Novel Coronavirus (COVID-19). International Journal of Surgery, 76, 71-76.

Suarjaya, I wayan,dkk. (2008). Panca Yajna. Denpasar: Widya Dharma.

Suasthi \& Suastawa. (2008). Psikologi Agama Seimbangkan Pikiran, Jiwa, dan Raga. Denpasar: Widya Dharma.

Velavan, P.T. \& Mayer G.C. (2020).The COVID-19 Epidemic. Tropical Medicine and International Health, 25(3), 278-280.

Wang, et al. (2020. Risk Management of COVID-19 by Universities in China. Journal of Risk and Financial Management, 13(2), 36. 
Wiana, I Ketut. (2009). Makna Hari Raya Hindu. Surabaya :Paramita.

Zhou, et al. (2020). The Role of Telehealth in Reducing the Mental Health Burden From COVID-19. Telemedicine and e-Health, 26(4),377-379. 